\title{
Controlling Structure and Reactivity in Cationic Solid-State Molecular Organometallic Systems Using Anion Templating
}

\author{
Alasdair I. McKay, ${ }^{\dagger}$ A Antonio J. Martínez-Martínez, ${ }^{\dagger}$ (๑) Hannah J. Griffiths, ${ }^{\dagger}$ Nicholas H. Rees, ${ }^{\dagger}$

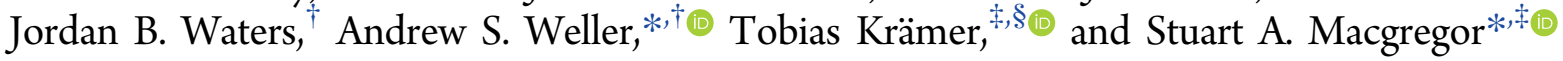 \\ ${ }^{\dagger}$ Department of Chemistry, University of Oxford, Mansfield Road, Oxford OX1 3TA, United Kingdom \\ ${ }^{\ddagger}$ Institute of Chemical Sciences, Heriot-Watt University, Edinburgh EH14 4AS, United Kingdom
}

\section{Supporting Information}

\begin{abstract}
The role that the supporting anion has on the stability, structure, and catalytic performance, in solid-state molecular organometallic systems (SMOM) based upon [Rh$\left.\left(\mathrm{Cy}_{2} \mathrm{PCH}_{2} \mathrm{CH}_{2} \mathrm{PCy}_{2}\right)\left(\eta^{2} \eta^{2}-\mathrm{NBD}\right)\right]\left[\mathrm{BAr}_{4}^{\mathrm{X}}\right],[\mathbf{1 - N B D}]\left[\mathrm{BAr}_{4}^{\mathrm{x}}\right]$, is reported $(\mathrm{X}=\mathrm{Cl}, \mathrm{F}, \mathrm{H} ; \mathrm{NBD}=$ norbornadiene $)$. The tetra-aryl borate anion is systematically varied at the 3,5-position, $\operatorname{Ar}^{\mathrm{X}}=3,5$ $\mathrm{X}_{2} \mathrm{C}_{6} \mathrm{H}_{3}$, and the stability and structure in the solid-state compared with the previously reported [1-NBD] $\left[\mathrm{BAr}_{4}^{\mathrm{CF} 3}{ }_{4}\right]$ complex. Single-crystal X-ray crystallography shows that the three complexes have different packing motifs, in which the cation sits on the shared face of two parallelepipeds for [1-

Solid-state Molecular OrganoMetallic Chemistry (SMOM)

Anion microenvironment determines stability \& binding selectivity of $\sigma$-alkane complexes

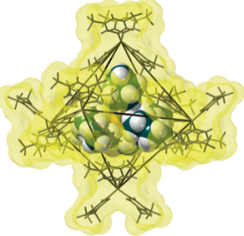

[1-NBA] $\left[B\left(\mathrm{C}_{6} \mathrm{H}_{3}\left(\mathrm{CF}_{3}\right)_{2}\right)_{4}\right]$

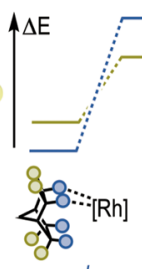

endo

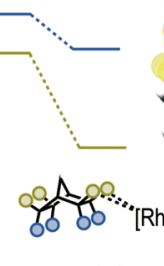

exo
$\mathrm{Rh} \cdots \mathrm{H}-\mathrm{C}$

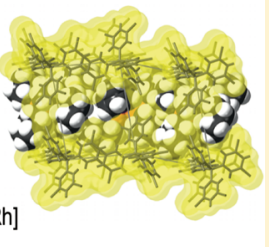

$[1-\mathrm{NBA}]\left[\mathrm{B}\left(\mathrm{C}_{6} \mathrm{H}_{3} \mathrm{Cl}_{2}\right)_{4}\right]$ $\mathrm{NBD}]\left[\mathrm{BAr}_{4}{ }_{4}\right]$, is surrounded by eight anions in a gyrobifastigium arrangement for [1-NBD] $\left.\mathrm{BAr}_{4}^{\mathrm{F}}\right]$, or the six anions show an octahedral cage arrangement in $[1-\mathrm{NBD}]\left[\mathrm{BAr}_{4}^{\mathrm{H}}\right]$, similar to that of $[1-\mathrm{NBD}]\left[\mathrm{BAr}{ }^{\mathrm{CF} 3}{ }_{4}\right] . \mathrm{C}-\mathrm{X} \cdots \mathrm{X}-\mathrm{C}$ contacts, commonly encountered in crystal-engineering, are suggested to be important in determining structure. Addition of $\mathrm{H}_{2}$ in a solid/gas reaction affords the resulting $\sigma$-alkane complexes, $\left[\mathrm{Rh}\left(\mathrm{Cy}_{2} \mathrm{PCH}_{2} \mathrm{CH}_{2} \mathrm{PCy}_{2}\right)\left(\eta^{2} \eta^{2}-\mathrm{NBA}\right)\right]\left[\mathrm{BAr}_{4}^{\mathrm{X}}\right][\mathbf{1 - N B A}]\left[\mathrm{BAr}_{4}^{\mathrm{X}}\right](\mathrm{NBA}=$ norbornane $)$, which can then proceed to lose the alkane and form the zwitterionic, anion-coordinated, complexes. The relative rates at which hydrogenation and then decomposition of $\sigma$-alkane complexes proceed are shown to be anion dependent. $\left[\mathrm{BAr}^{\mathrm{CF} 3}{ }_{4}\right]^{-}$promotes fast hydrogenation and an indefinitely stable $\sigma$-alkane complex. With $\left[\mathbf{B A r}{ }_{4}{ }_{4}\right]^{-}$hydrogenation is slow and the $\sigma$-alkane complex so unstable it is not observed. $\left[\mathrm{BAr}_{4}\right]^{-}$and $\left[\mathrm{BAr}_{4}^{\mathrm{F}}\right]^{-}$promote intermediate reactivity profiles, and for $\left[\mathrm{BAr}_{4}\right]^{-}$, a single-crystal to single-crystal hydrogenation results in $[1-N B A]\left[\mathbf{B A r}^{\mathrm{Cl}}{ }_{4}\right]$. The molecular structure derived from X-ray diffraction reveals a $\sigma$ alkane complex in which the NBA fragment is bound through two exo $\mathrm{Rh} \cdots \mathrm{H}-\mathrm{C}$ interactions-different from the endo selective binding observed with $[1-\mathrm{NBA}]\left[\mathrm{BAr}^{\mathrm{CF} 3}{ }_{4}\right]$. Periodic DFT calculations demonstrate that this selectivity is driven by the microenvironment dictated by the surrounding anions. [1-NBA] $\left[\mathbf{B A r}^{\mathbf{X}}{ }_{4}\right]$ are catalysts for gas/solid 1-butene isomerization (298 $\mathrm{K}, 1 \mathrm{~atm}$ ), and their activity can be directly correlated to the stability of the $\sigma$-alkane complex compared to the anion-coordinated decomposition products.
\end{abstract}

\section{INTRODUCTION}

The functionalization of alkanes via $\mathrm{C}-\mathrm{H}$ activation to produce commodity and fine chemicals or new materials is of considerable contemporary interest. ${ }^{1-4} \sigma$-Alkane complexes, in which the $\mathrm{C}-\mathrm{H}$ bond engages in a 3-center 2-electron interaction with the metal center, ${ }^{5}$ have long been recognized as key intermediates in $\mathrm{C}-\mathrm{H}$ activation processes that occur by an inner-sphere mechansim. ${ }^{6-12} \sigma$-Alkane complexes are also of interest in terms of their challenging, but fundamentally important, coordination chemistry. The strong nonpolar C$\mathrm{H}$ bond in alkanes, combined with the steric hindrance of proximal groups, mean that alkanes are very poor ligands, typically binding to metal centers with bond enthalpies of $\sim 60$ kJ $\mathrm{mol}^{-1}$ or less. ${ }^{9,13,14}$ The characterization of $\sigma$-alkane complexes has been generally limited to very low-temperature, in situ, solution-based spectroscopic studies, e.g., TRIR or NMR spectroscopy, either by photogeneration of a coordinatively unsaturated metal center in a solvent that also acts as a proligand $^{15-18}$ or protonation of a metal-alkyl complex with a strong acid, ${ }^{19,20}$ for example, $\left[\operatorname{Re}(\mathrm{HEB})(\mathrm{CO})_{2}(\mathrm{CypH})\right][\mathrm{Al}-$ $\left.\left\{\mathrm{OC}\left(\mathrm{CF}_{3}\right)_{3}\right\}_{4}\right] \quad\left(\mathrm{HEB}=\eta^{6}\right.$-hexaethylbenzene, Cyp $=$ cyclopentyl $)^{21}$ or $\left[\mathrm{Rh}(\mathrm{PONOP})\left(\mathrm{H}_{4} \mathrm{C}\right)\right]\left[\mathrm{BAr}_{4}^{\mathrm{CF}}{ }_{4}\right]$ (PONOP = $\left.\left(2,6-{ }^{\mathrm{t}} \mathrm{Bu}_{2} \mathrm{PO}\right)_{2} \mathrm{C}_{5} \mathrm{H}_{3} \mathrm{~N}, \mathrm{Ar}^{\mathrm{CF} 3}=3,5-\left(\mathrm{CF}_{3}\right)_{2}\left(\mathrm{C}_{6} \mathrm{H}_{3}\right)\right)$, respectively. Although these elegant techniques allow for the direct observation of $\sigma$-alkane complexes by NMR spectroscopy, these are generated in low absolute quantities, e.g., $1-20 \mathrm{mg}$, and are relatively short-lived, e.g., half-lives of less than $90 \mathrm{~min}$ at $212 \mathrm{~K}$. This makes such routes less than optimal for the generation of materials suitable for structural elucidation by single-crystal X-ray diffraction techniques or onward reactivity studies. We recently reported an alternative route to form $\sigma$ -

Special Issue: In Honor of the Career of Ernesto Carmona

Received: April 11, 2018

Published: June 4, 2018 
alkane complexes directly in the solid-state by solid/gas singlecrystal to single-crystal transformations, ${ }^{22,23}$ thereby enabling the structure of the product to be directly determined by singlecrystal X-ray diffraction and solid-state NMR techniques. It also allows for structures to be further interrogated by periodic DFT computational analysis. Exemplifying this approach, addition of $\mathrm{H}_{2}$ to the diene precursor $\left[\mathrm{Rh}\left(\mathrm{Cy}_{2} \mathrm{PCH}_{2} \mathrm{CH}_{2} \mathrm{PCy}_{2}\right)\left(\eta^{2} \eta^{2}\right.\right.$ $\mathrm{NBD})]\left[\mathrm{BAr}_{4}^{\mathrm{CF} 3}\right],[\mathbf{1 - N B D}]\left[\mathrm{BAr}_{4}^{\mathrm{CF} 3}{ }_{4}\right](\mathrm{NBD}=$ norbornadiene $)$, affords $\left[\mathrm{Rh}\left(\mathrm{Cy}_{2} \mathrm{PCH}_{2} \mathrm{CH}_{2} \mathrm{PCy}_{2}\right)\left(\eta^{2} \eta^{2}-\mathrm{NBA}\right)\right]\left[\mathrm{BAr}^{\mathrm{CF} 3}{ }_{4}\right]$ ([1-NBA] $\left[\mathrm{BAr}_{4}^{\mathrm{CF} 3}{ }_{4}\right], \mathrm{NBA}=$ norbornane) in essentially quantitative yield (Figure $1 \mathrm{~A}),{ }^{24}$ in which a saturated NBA

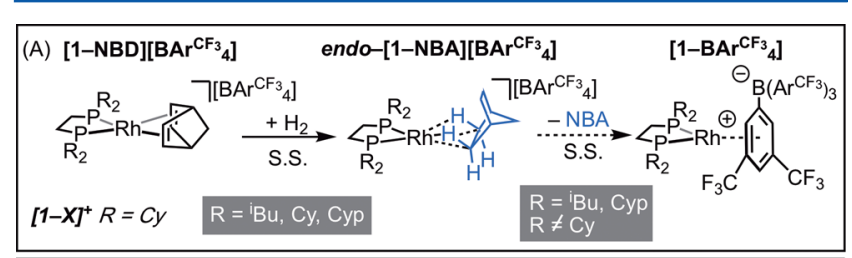

(B)
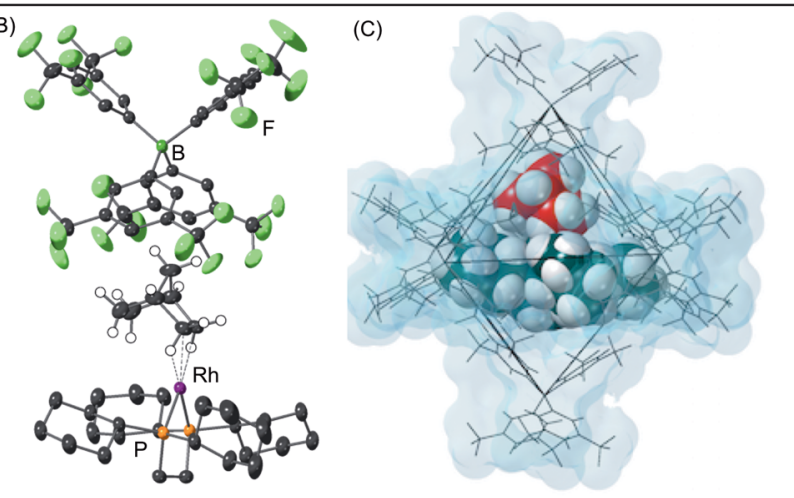

Figure 1. (A) Synthesis of $\sigma$-alkane complexes in the solid-state. (B) Solid-state structure of $[1-\mathrm{NBA}]\left[\mathrm{BAr}^{\mathrm{CF} 3}{ }_{4}\right]$. (C) Packing of anions around a single cation (van der Waals radii).

fragment interacts with the Rh-center through two endo-C-H... $\mathrm{Rh} 3 \mathrm{c}-2 \mathrm{e}$ interactions. This complex is remarkably stable in the solid-state (months at $298 \mathrm{~K}$ under $\mathrm{Ar}$ ) with respect to NBA loss and formation of the $\left[\mathrm{BAr}^{\mathrm{CF} 3}\right]^{-}$coordinated zwitterion, $\left[\mathrm{Rh}\left(\mathrm{Cy}_{2} \mathrm{PCH}_{2} \mathrm{CH}_{2} \mathrm{PCy}_{2}\right)\left\{\left(\eta^{6}-\mathrm{C}_{6} \mathrm{H}_{3}\left(\mathrm{CF}_{3}\right)_{2}\right) \mathrm{BAr}_{3}^{\mathrm{CF} 3}\right\}\right], \quad[\mathbf{1}-$ BAr ${ }_{4}{ }_{4}{ }_{4}$. With other substituents on phosphorus, stability is significantly reduced. For example, when $\mathrm{R}=$ cyclopentyl (Суp) a lifetime of $96 \mathrm{~h}$ is measured, ${ }^{25}$ while when $\mathrm{R}={ }^{\mathrm{i}} \mathrm{Bu}$, stability at $298 \mathrm{~K}$ is limited to only a few hours. ${ }^{26}$ Stability is enhanced at lower temperatures, allowing for characterization by single-crystal X-ray diffraction techniques at $150 \mathrm{~K}$. We speculate that the general stability in the solid-state of $\sigma$-alkane complexes such as $[\mathbf{1 - N B A}]\left[\mathbf{B A r}_{4}^{\mathrm{CF} 3}\right]$ and its analogues originates from an octahedral cavity defined by the $\left[\mathrm{BAr}_{4}^{\mathrm{CF} 3}\right]^{-}$ anions (Figure $1 \mathrm{~B}, \mathrm{C}$ ), which permits the hydrogenation of the alkene to occur without loss of crystallinity, trapping the resultant alkane. These anions thus provide a microenvironment that allows for transformations within a crystalline "molecular flask". ${ }^{27} \mathrm{We}$ describe these exceptionally welldefined systems as solid-state molecular organometallics (SMOM) in reference to related and well-developed supported organometallic catalysts (SOMC) ${ }^{28}$ and single-site heterogeneous catalysts (SSHC), ${ }^{29}$ and like these systems, they support transformations such as alkane $\mathrm{C}-\mathrm{H}$ activation ${ }^{30}$ and catalysis, e.g., solid/gas alkene isomerization. ${ }^{31}$

The precise factors governing the variation of relative stabilities of these complexes on changing the phosphine ligand are not fully resolved, although we have noted that the steric profile appears to be important, ${ }^{25}$ while a number of weak $\mathrm{C}-\mathrm{H} \cdots \mathrm{F}-\mathrm{C}$ hydrogen bonds in the extended lattice may contribute to kinetic and/or thermodynamic stability. ${ }^{24}$ In this contribution we concentrate on the role that the supporting anion has on the stability, structure, and catalytic performance of SMOM-catalysts based upon $[\mathbf{1 - N B A}]^{+}$, in which the anion is systematically varied (Scheme 1) using various tetra-aryl

Scheme 1. SMOM Systems Studied in This Contribution

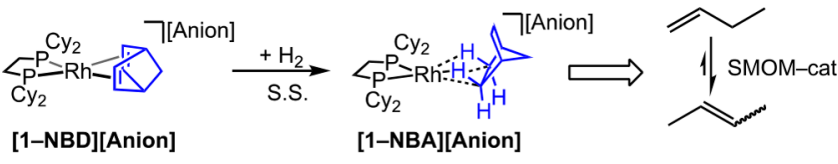<smiles>CC(C)(C)C(F)(F)C(F)(F)c1cc(F)cc(B(c2cc(F)cc(C(F)(F)F)c2)c2cc(C(F)(F)F)cc(C(F)(F)C(F)(F)F)c2)c1</smiles>

borates in which substitution at the 3,5-position is changed. Although anion effects are well-documented in homogeneous organometallic chemistry and catalysis, ${ }^{32,33}$ their influence in the solid-state with regard to single-crystal to single-crystal synthesis and catalysis is considerably less well developed. ${ }^{34-37}$

\section{RESULTS AND DISCUSSION}

2.1. Variation of the Borate Anion in the 3,5 Positions: Effects on Structure. New precursor complexes [1-NBD]$\left[\mathbf{B A r}^{\mathrm{Cl}}{ }_{4}\right]\left(\mathrm{Ar}^{\mathrm{Cl}}=3,5-\mathrm{Cl}_{2} \mathrm{C}_{6} \mathrm{H}_{3}\right),[\mathbf{1}-\mathrm{NBD}]\left[\mathbf{B A r}^{\mathrm{F}}{ }_{4}\right]\left(\mathrm{Ar}^{\mathrm{F}}=3,5-\right.$ $\left.\mathrm{F}_{2} \mathrm{C}_{6} \mathrm{H}_{3}\right)$, and $[\mathbf{1}-\mathrm{NBD}]\left[\mathbf{B A r}^{\mathrm{H}}{ }_{4}\right]\left(\mathrm{Ar}^{\mathrm{H}}=\mathrm{C}_{6} \mathrm{H}_{5}\right)$ were synthesized by addition of the respective sodium borate salt to a dichloromethane solution of $\left[\mathrm{RhCl}\left(\mathrm{Cy}_{2} \mathrm{PCH}_{2} \mathrm{CH}_{2} \mathrm{PCy}_{2}\right)\right]_{2}$ in the presence of excess NBD (Scheme 2).

\section{Scheme 2. Synthesis of NBD Precursor Complexes}

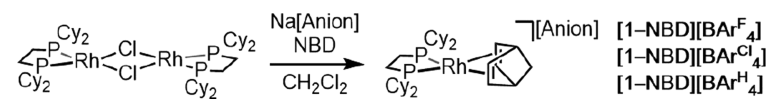

Solution NMR data are fully consistent with their formulation (Supporting Information) being similar to previously reported examples. ${ }^{24,38}$ Orange single-crystals suitable for single-crystal $\mathrm{X}$-ray diffraction could be grown from $\mathrm{CH}_{2} \mathrm{Cl}_{2}$ /pentane solvent mixtures, and the resulting solidstate structures determined are shown in Figure 2. The effect of the anions on the solid-state structure is signaled by the three complexes crystallizing in different space groups: [1-NBD]$\left[\mathbf{B A r}_{4}{ }_{4}\right] P \overline{1}\left(Z^{\prime}=1\right),[1-N B D]\left[\mathbf{B A r}^{\mathrm{F}}{ }_{4}\right] F d d 2\left(Z^{\prime}=0.5\right)$, and $[1-N B D]\left[\mathbf{B A r}_{4}{ }_{4}\right] \quad P b c a \quad\left(Z^{\prime}=1\right)$. The cations show 

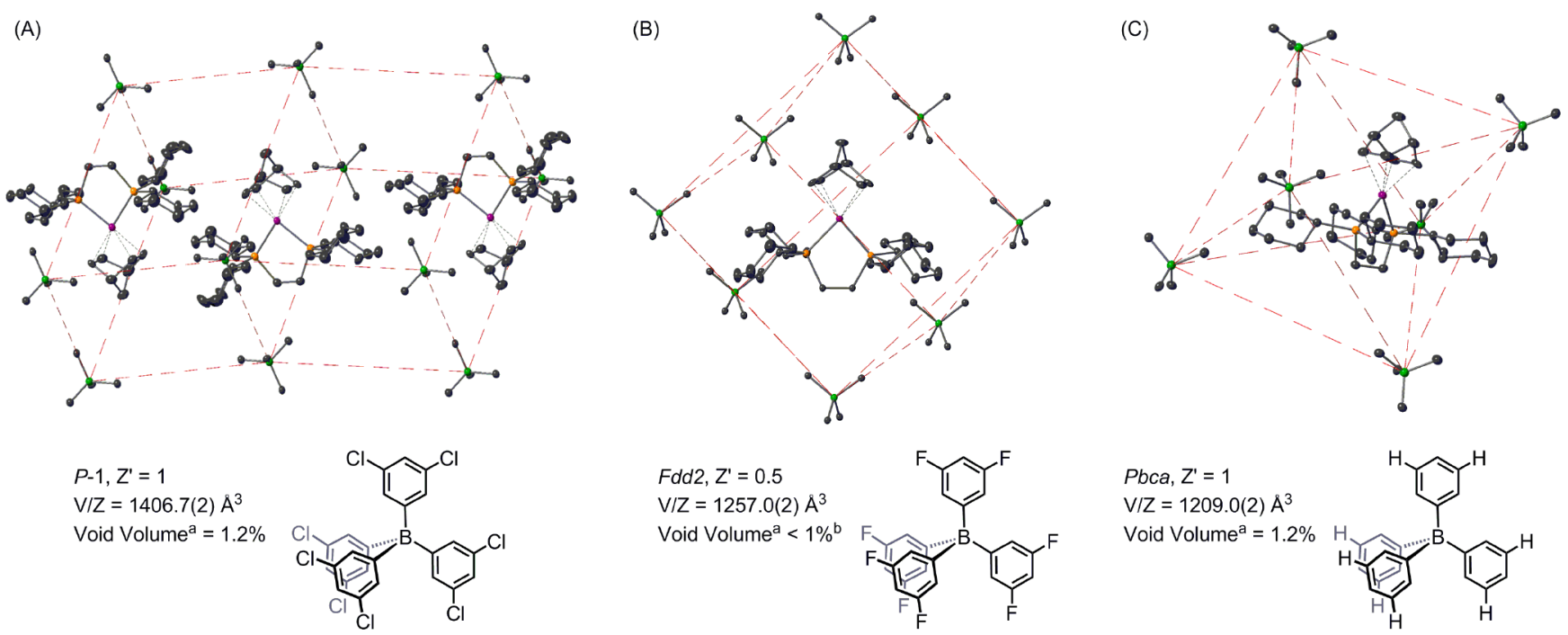

Figure 2. Extended solid-state structures of (A) $[1-N B D]\left[\mathrm{BAr}_{4}^{\mathrm{Cl}}\right]$; (B) $[\mathbf{1 - N B D}]\left[\mathrm{BAr}_{4}^{\mathrm{F}}\right]$; (C) [1-NBD] $\left[\mathrm{BAr}^{\mathrm{H}}{ }_{4}\right]$. Ar ${ }^{\mathrm{X}}$ groups omitted. ${ }^{\mathrm{a}}$ Solvent

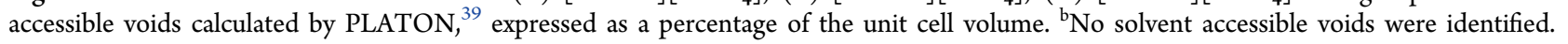

unremarkable structural metrics, being very similar to that of the parent complex $[1-\mathrm{NBD}]\left[\mathrm{BAr}_{4}^{\mathrm{CP}}{ }_{4}\right]$. However, consideration of the packing of the anions in the lattice shows a dramatic difference between all three. For [1-NBD] $\left[\mathrm{BAr}_{4}^{\mathrm{Cl}}\right]$, the cation sits on the shared face of two parallelepipeds, but there is no crystallographically imposed symmetry. In [1$\mathrm{NBD}]\left[\mathrm{BAr}^{\mathrm{F}}{ }_{4}\right]$ the cation is surrounded by eight anions which adopt a gyrobifastigium arrangement (two face-sharing trigonal prisms rotated $90^{\circ}$ to one another) and sits on a special position generating $C_{2}$ symmetry. For $[\mathbf{1 - N B D}]\left[\mathbf{B A r}_{4}^{\mathrm{H}}{ }_{4}\right]$, each cation is surrounded by six anions in an octahedral cage arrangement, similar to that in $[\mathbf{1 - N B D}]\left[\mathrm{BAr}^{\mathrm{CF} 3}{ }_{4}\right](P \overline{1}, Z=$ 2). ${ }^{24}$ However, unlike in $[\mathbf{1 - N B D}]\left[\mathrm{BAr}_{4}^{\mathrm{CF} 3}{ }_{4}\right]$ where the $\{\mathrm{Rh}(\mathrm{NBD})\}$ points toward the apical borate and is flanked by two of its $\mathrm{Ar}^{\mathrm{CF} 3}$ groups, the $\mathrm{NBD}$ ligand in [1$\mathrm{NBD}]\left[\mathrm{BAr}_{4}^{\mathrm{H}}{ }_{4}\right]$ points to an edge of the octahedron (Figures $1 \mathrm{~B}$ and $2 \mathrm{C}$ ). This is a consequence of the different local orientation of the $\left[\mathrm{BAr}_{4}^{\mathrm{H}}\right]^{-}$anions compared to $\left[\mathrm{BAr}{ }_{4}^{\mathrm{CF} 3}\right]^{-}$in which aryl groups of the former penetrate the cavity of the octahedron (Supporting Information) and for which the volume is also smaller (average cross-cage B $\cdots \mathrm{B}$ distances of 16.9 and $18.8 \AA$, respectively).

The extended solid-state structures of both $[1-N B D]\left[\mathrm{BAr}_{4}{ }_{4}\right]$ and $[1-N B D]\left[\mathrm{BAr}^{\mathrm{Cl}}{ }_{4}\right]$ display interanion contacts. In [1$\mathrm{NBD}]\left[\mathrm{BAr}^{\mathrm{F}}{ }_{4}\right]$, the $\mathrm{F} 1 \cdots \mathrm{H} 27$ distance of $2.465(2) \AA$ (Figure $3 B)$ lies well within the combined van der Waals radii of $F$ and $\mathrm{H}(2.66 \AA)^{40}$ being comparable to that reported in the solid-

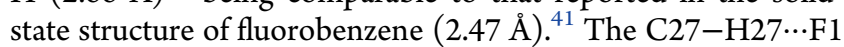
angle is essentially linear, $174.4(2)^{\circ}$. For $[1-N B D]\left[\mathrm{BAr}_{4}{ }_{4}\right]$, a number of interanion chlorine $\cdots$ chlorine contacts ( $\mathrm{Cl} 1 \cdots \mathrm{Cl} 6$

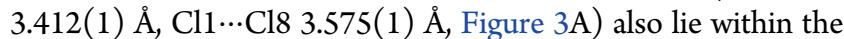
combined van der Waals radii $(3.64 \AA)^{40}$ and are arranged close to $90^{\circ}\left[100.97(9)\right.$ and $80.35(8)^{\circ}$, respectively]. These are best described as Type II C-X $\cdots \mathrm{X}-\mathrm{C}$ contacts, ${ }^{42}$ which are similar to those observed in the solid-state structure of 1,3dichlorobenzene. $^{43}$ These types of halogen $\cdots$ hydrogen ${ }^{44}$ and halogen $\cdots$ halogen ${ }^{45}$ contacts have been widely utilized in crystal engineering. ${ }^{46}$ Given that these two anions are essentially isosteric, these interactions, albeit weak, clearly influence the extended packing motif in the lattice. Long interanion contacts are observed in the solid-state structure of $[1-\mathrm{NBD}]\left[\mathrm{BAr}^{\mathrm{CF} 3}{ }_{4}\right]$
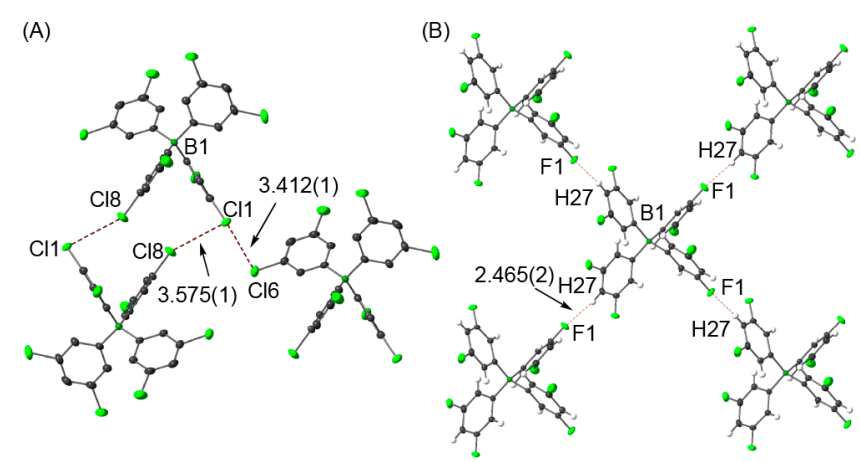

Figure 3. Interanion interactions in the solid-state structures of (A) $[1-\mathrm{NBD}]\left[\mathrm{BAr}_{4}^{\mathrm{Cl}}\right]$ and (B) $[1-\mathrm{NBD}]\left[\mathrm{BAr}^{\mathrm{F}}{ }_{4}\right]$.

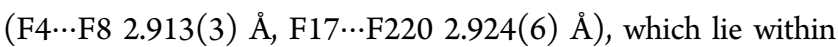
error of the combined van der Waals radii $(2.92 \AA) .{ }^{40}$ There are no interanion contacts in $[\mathbf{1 - N B D}]\left[\mathrm{BAr}^{\mathrm{H}}{ }_{4}\right]$ that lie within the sum of van der Waals radii.

These new NBD complexes have been studied by solid-state NMR (SSNMR) techniques at $294 \mathrm{~K}$. The ${ }^{31} \mathrm{P}\left\{{ }^{1} \mathrm{H}\right\}$ SSNMR spectrum of $[1-\mathrm{NBD}]\left[\mathrm{BAr}_{4}^{\mathrm{Cl}}\right]$ features two distinct but closely spaced phosphine environments $[\delta 64.7, J(\mathrm{RhP})=145 \mathrm{~Hz} ; \delta$ 63.0, $J(\mathrm{RhP})=147 \mathrm{~Hz}]$. Similarly, for $[1-\mathrm{NBD}]\left[\mathrm{BAr}^{\mathrm{H}}{ }_{4}\right]$, two phosphine environments are observed $[\delta 75.8, J(\mathrm{RhP})=134$ $\mathrm{Hz} ; \delta 64.8, J(\mathrm{RhP})=132 \mathrm{~Hz}$. The observation of two ${ }^{31} \mathrm{P}$ environments is consistent with the solid-state structures that have crystallographically nonequivalent phosphines. In contrast, the ${ }^{31} \mathrm{P}\left\{{ }^{1} \mathrm{H}\right\}$ SSNMR spectrum of [1-NBD] $\left[\mathrm{BAr}^{\mathrm{F}}{ }_{4}\right]$ displays a single, broad ${ }^{31} \mathrm{P}$ environment at $\delta 70.9$, consistent with the $C_{2}$ symmetry observed in its solid-state structure, although coupling to ${ }^{103} \mathrm{Rh}$ was not resolved. These features are mirrored in the corresponding ${ }^{13} \mathrm{C}\left\{{ }^{1} \mathrm{H}\right\}$ SSNMR spectra. [1-NBD]$\left[\mathrm{BAr}_{4}{ }_{4}\right]$ and $[\mathbf{1 - N B D}]\left[\mathrm{BAr}^{\mathrm{H}}{ }_{4}\right]$ each feature six signals ${ }^{47}$ between $\delta 90$ and 50, which are assigned to the NBD fragment, while the ${ }^{13} \mathrm{C}\left\{{ }^{1} \mathrm{H}\right\}$ SSNMR spectrum of $[\mathbf{1 - N B D}]\left[\mathbf{B A r}^{\mathrm{F}}{ }_{4}\right]$ displays four distinct signals assigned to the NBD fragment under crystallographic $C_{2}$ symmetry.

2.2. Reactivity of [1-NBD][BAr $\left.{ }_{4}\right](X=\mathrm{Cl}, \mathrm{F}, \mathrm{H})$ with $\mathrm{H}_{2}$ in the Solid-State as Studied by NMR Spectroscopy. With the complexes [1-NBD] $\left[\mathbf{B A r}^{\mathrm{X}}{ }_{4}\right]$ in hand their solid/gas 
reactivity with $\mathrm{H}_{2}$ was studied with respect to changing the anion-identity, and compared against [1-NBD] $\left[\right.$ BAr $\left.^{\mathrm{CF} 3}{ }_{4}\right]$. Finely powdered single crystals of $[1-\mathrm{NBD}]\left[\mathrm{BAr}_{4}{ }_{4}\right]$ were exposed to $\mathrm{H}_{2}$ ( $1 \mathrm{bar}, 298 \mathrm{~K}$ ) for various periods of time, $\mathrm{H}_{2}$ was then removed under vacuum, dichloromethane was added by vacuum transfer and the sample warmed to $298 \mathrm{~K}$. The extent of hydrogenation was determined by comparing the relative integrals in the ${ }^{31} \mathrm{P}\left\{{ }^{1} \mathrm{H}\right\}$ NMR spectrum of the starting material and zwitterionic [1-BAr ${ }_{4}{ }_{4}$ ] (Figure 4A). Complexes

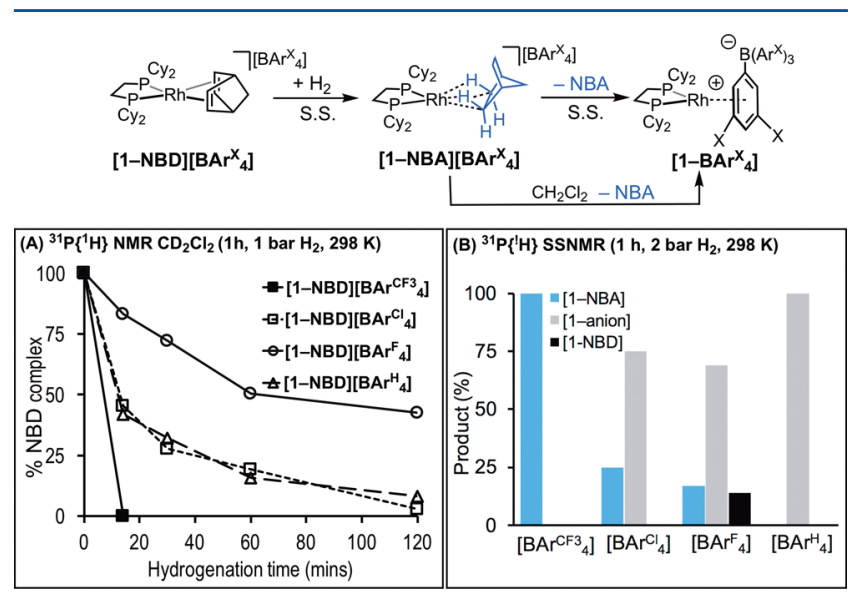

Figure 4. (A) Temporal evolution of $\mathrm{H}_{2}$ addition (1 bar, $298 \mathrm{~K}$, first 2 h) to $[1-N B D]\left[\mathrm{BAr}_{4}{ }_{4}\right]\left(\mathrm{X}=\mathrm{Cl}, \mathrm{F}, \mathrm{H}, \mathrm{CF}_{3}\right)$ as measured by the formation of $\left[1-\mathrm{BAr}_{4}{ }_{4}\right]$ in $\mathrm{CD}_{2} \mathrm{Cl}_{2}$ solution. ${ }^{48}$ (B) Selectivity of [1NBA $]\left[\right.$ BAr $\left._{4}{ }_{4}\right]$ formation after $\mathrm{H}_{2}$ addition (2 bar, $298 \mathrm{~K}, 1 \mathrm{~h}$ ) as measured by ${ }^{31} \mathrm{P}\left\{{ }^{1} \mathrm{H}\right\}$ SSNMR at $158 \mathrm{~K}$.

[1-BAr ${ }_{4}^{\mathrm{X}}$ ] have been independently prepared and characterized (Supporting Information). ${ }^{48}$ This methodology only indirectly signals the formation of a $\sigma$-alkane complex, i.e., [1-NBA]$\left[\mathbf{B A r}_{4}{ }_{4}\right]$, as the alkane would be rapidly displaced by the anion on solvation. ${ }^{24}$ However, it does allow for the expedient measurement of the relative rates of hydrogenation in the solidstate.

These data reveal the rate of NBD hydrogenation to be anion-dependent, with replacement of the 3,5-( $\left(\mathrm{CF}_{3}\right)_{2}$ substituents on the borate resulting in significantly slower reactions. For $[1-N B D]\left[\mathrm{BAr}_{4}^{\mathrm{F}}\right]$, hydrogenation of the NBD ligand is only complete after $\sim 24 \mathrm{~h}$. By contrast, [1NBD] $\left[\mathrm{BAr}_{4}{ }_{4}\right]$ and $[\mathbf{1 - N B D}]\left[\mathrm{BAr}_{4}^{\mathrm{H}}\right]$ are both hydrogenated in $2 \mathrm{~h}$, although this is still considerably slower than for [1NBD] $\left[\mathrm{BAr}^{\mathrm{CF} 3}{ }_{4}\right]$ for which a maximum time of $15 \mathrm{~min}$ is obtained (first measured point). These different rates of hydrogenation are also signaled by color changes to the crystalline material. While orange microcrystalline [1-NBD]$\left[\mathrm{BAr}^{\mathrm{Cl}}{ }_{4}\right]$ and $[\mathbf{1 - N B D}]\left[\mathrm{BAr}^{\mathrm{F}}{ }_{4}\right]$ undergo little immediate color change, over longer times $(3 \mathrm{~h})$ the color of the powder changed to yellow which is characteristic of zwitterion formation. For $[1-\mathrm{NBD}]\left[\mathrm{BAr}^{\mathrm{H}}{ }_{4}\right]$, this color change was more rapid $(10 \mathrm{~min})$.

Following the hydrogenation in the solid-state $(2 \mathrm{bar}, 1 \mathrm{~h}$, $298 \mathrm{~K})^{49}$ of $[1-N B D]\left[\mathrm{BAr}_{4}^{\mathrm{Cl}}\right]$ by ${ }^{31} \mathrm{P}\left\{{ }^{1} \mathrm{H}\right\}$ SSNMR spectroscopy (measured at $158 \mathrm{~K}$ to slow decomposition - vide infra) revealed complete consumption of the starting material to form an intermediate species $[\delta 102.7, J(\mathrm{RhP}) \approx 180 \mathrm{~Hz} ; \delta$ 97.2, $J(\mathrm{RhP}) \approx 198 \mathrm{~Hz}]$. These data are similar to those reported for $[1-\mathrm{NBA}]\left[\mathrm{BAr}^{\mathrm{CF} 3}{ }_{4}\right][\delta \sim 110, J(\mathrm{RhP}) \approx 207$ and $216 \mathrm{~Hz}]$ (Figure 4B). ${ }^{24}$ The ${ }^{13} \mathrm{C}\left\{{ }^{1} \mathrm{H}\right\}$ SSNMR spectrum confirmed that hydrogenation of the alkene had occurred, with the disappearance of diagnostic signals at $\delta 88.4,87.4,80.3$, and 79.4 assigned to alkene in the starting material. These data signal the formation of a $\sigma$-alkane complex $[1-\mathrm{NBA}]\left[\mathrm{BAr}_{4}^{\mathrm{Cl}}\right]$. The ${ }^{31} \mathrm{P}\left\{{ }^{1} \mathrm{H}\right\}$ SSNMR resonances were accompanied by a broad signal centered at $\delta 86$ (relative ratio 25:75), assigned to the amorphous decomposition product $\left[1-\mathrm{BAr}^{\mathrm{Cl}}{ }_{4}\right]$ which has been independently synthesized and crystallographically characterized and is similar to that reported for [ $\mathrm{Rh}$ $\left.\left({ }^{\mathrm{i}} \mathrm{Bu}_{2} \mathrm{PCH}_{2} \mathrm{CH}_{2} \mathrm{P}^{\mathrm{i}} \mathrm{Bu}_{2}\right)\left\{\left(\eta^{6}-\mathrm{C}_{6} \mathrm{H}_{3} \mathrm{Cl}_{2}\right) \mathrm{BAr}_{3}^{\mathrm{Cl}}\right\}\right]$ (see the Supporting Information). ${ }^{38}$ We have not observed [1-NBA] $]\left[\mathbf{B A r}^{\mathrm{Cl}}{ }_{4}\right]$ free of zwitterion product; however, low temperatures halt onward decomposition. Complete decomposition of [1-NBA]$\left[\mathrm{BAr}_{4}{ }_{4}\right]$ occurs in $7 \mathrm{~h}$ at $294 \mathrm{~K}$. This stability of [1$\mathrm{NBA}]\left[\mathrm{BAr}_{4}{ }_{4}\right]$ is notable considering that the room temperature hydrogenation of microcrystalline [ $\mathrm{Rh}$ $\left.\left({ }^{\mathrm{i}} \mathrm{Bu}_{2} \mathrm{PCH}_{2} \mathrm{CH}_{2} \mathrm{P}^{\mathrm{i}} \mathrm{Bu}_{2}\right)\left(\eta^{2} \eta^{2}-\mathrm{NBD}\right)\right]\left[\mathrm{BAr}_{4}{ }_{4}\right]$ affords [Rh$\left.\left({ }^{\mathrm{i}} \mathrm{Bu}_{2} \mathrm{PCH}_{2} \mathrm{CH}_{2} \mathrm{P}^{\mathrm{i}} \mathrm{Bu}_{2}\right)\left\{\left(\eta^{6}-\mathrm{C}_{6} \mathrm{H}_{3} \mathrm{Cl}_{2}\right) \mathrm{BAr}{ }_{3}{ }_{3}\right\}\right]$ quantitatively in $10 \mathrm{~min}$ and no intermediate alkane $\sigma$ complex is observed, ${ }^{38}$ reflecting the influence of the phosphine steric-profile on $\sigma$ complex stability.

Although hydrogenation of $[1-\mathrm{NBD}]\left[\mathrm{BAr}^{\mathrm{H}}{ }_{4}\right]$ occurs at the same rate as [1-NBA] $\left[\mathbf{B A r}^{\mathrm{Cl}}{ }_{4}\right]$ (Figure $4 \mathrm{~A}$ ) an intermediate alkane complex is not observed. The ${ }^{31} \mathrm{P}\left\{{ }^{1} \mathrm{H}\right\}$ SSNMR spectrum $(158 \mathrm{~K}$, Figure 5D) of hydrogenated microcrystalline

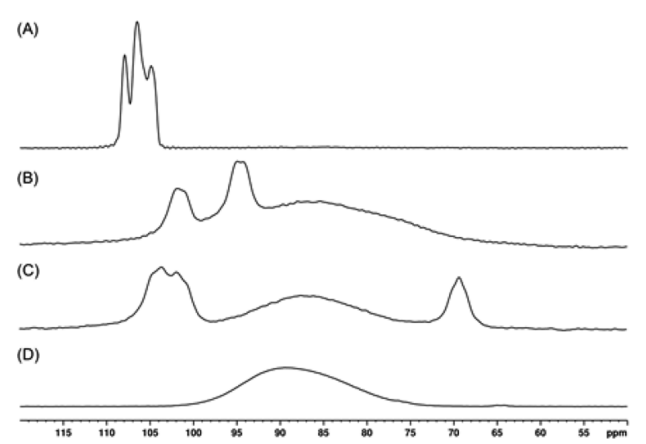

Figure 5. ${ }^{31} \mathrm{P}\left\{{ }^{1} \mathrm{H}\right\}$ SSNMR spectra $\left(158 \mathrm{~K}\right.$ ) of $\mathrm{H}_{2}$ addition (2 bar, 298 $\mathrm{K}, 1 \mathrm{~h})$ to powdered crystalline $[\mathbf{1}-\mathrm{NBD}]\left[\mathrm{BAr}_{4}{ }_{4}\right]$. (A) [1-NBD]$\left[\mathrm{BAr}^{\mathrm{CF}}{ }_{4}\right]$; (B) $[\mathbf{1 - N B D}]\left[\mathrm{BAr}^{\mathrm{Cl}}{ }_{4}\right]$; (C) $[1-\mathrm{NBD}]\left[\mathrm{BAr}^{\mathrm{F}}{ }_{4}\right]$; (D) $[1-$ $\mathrm{NBD}]\left[\mathrm{BAr}_{4}^{\mathrm{H}}\right]$.

$[1-N B D]\left[\mathrm{BAr}_{4}^{\mathrm{H}}\right]$ (2 bar, $\left.1 \mathrm{~h}, 298 \mathrm{~K}\right)$, features a single very broad resonance centered at $\delta 89.0$, which is assigned to the amorphous zwitterionic decomposition product $\left[1-\mathbf{B A r}_{4}^{\mathrm{H}}\right]$, which has been independently prepared (Supporting Information). Zwitterionic complexes such as $\mathrm{Rh}\left(\mathrm{PR}_{3}\right)_{2}\left\{\left(\eta^{6}-\mathrm{C}_{6} \mathrm{H}_{5}\right)\right.$ $\left.\mathrm{BAr}_{3}{ }_{3}\right\}$ are well-known. ${ }^{30-54}$ No signals were observed that could be assigned to a $\sigma$-alkane complex. For $[1-\mathrm{NBD}]\left[\mathrm{BAr}_{4}^{\mathrm{F}}\right]$, after hydrogenation for $1 \mathrm{~h}$, two broad closely spaced downfield doublets where observed $[\delta 105.1, J(\mathrm{RhP}) \approx 180 \mathrm{~Hz} ; \delta 102.2$, $J(\mathrm{RhP}) \approx 190 \mathrm{~Hz}]$ that are assigned to $\sigma$-alkane complex $[1-$ NBA] $\left[\right.$ BAr $\left.^{\mathrm{F}}{ }_{4}\right]$. However, a very broad resonance $[\delta 89.3$, ca. $69 \%$ ] also dominates, assigned to an amorphous phase of zwitterionic $\left[1-\mathrm{BAr}^{\mathrm{F}}{ }_{4}\right.$ ], in addition to starting material $(14 \%)$. $\left[1-\mathrm{BAr}^{\mathrm{F}}{ }_{4}\right]$ has been independently synthesized and crystallographically characterized (Figure 6 and Supporting Information) and presents a rare example of this anion coordinating with a metal center in an $\eta^{6}$-motif. Structures showing $\kappa^{1}-$ and $\kappa^{2}-\mathrm{F} \cdots \mathrm{M}$ interactions ${ }^{55,56}$ with the $\left[\mathrm{B}\left(\mathrm{C}_{6} \mathrm{~F}_{5}\right)_{4}\right]^{-}$are known. These data are consistent with not only the slower rate of hydrogenation in the solid-state for $[1-N B D]\left[\mathbf{B A r}^{\mathrm{F}}{ }_{4}\right]$ but also that the stability of $[\mathbf{1}-\mathrm{NBA}]\left[\mathrm{BAr}^{\mathrm{F}}{ }_{4}\right]$ with respect to zwitterion 


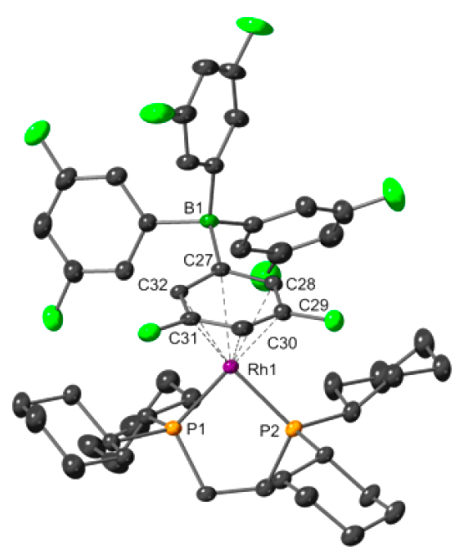

Figure 6. Solid-state structure of $\left[1-\mathrm{BAr}^{\mathrm{F}}\right.$ ]. Displacement ellipsoids are shown at $50 \%$ probability level, second molecule in the asymmetric unit and hydrogen atoms omitted for clarity. Selected bond distances (A): Rh1-P1 2.2631(5), Rh1-P2 2.2449(5), Rh1-C27 2.4604(18), Rh1-C28 2.3423(18), Rh1-C29 2.2802(18), Rh1-C30 2.3908(18), Rh1-C31 2.3194(18), Rh1-C32 2.3185(18).

formation must be sufficient to allow for its observation, albeit not as the major species after $1 \mathrm{~h}$. The broad signals observed in the ${ }^{31} \mathrm{P}\left\{{ }^{1} \mathrm{H}\right\}$ SSNMR that are assigned to amorphous phases of these zwitterionic complexes have been noted previously for $\left[\mathrm{Rh}\left({ }^{\mathrm{i}} \mathrm{Pr}_{2} \mathrm{PCH}_{2} \mathrm{CH}_{2} \mathrm{P}^{\mathrm{i}} \mathrm{Pr}_{2}\right)\left\{\left(\eta^{6}-\mathrm{C}_{6} \mathrm{H}_{3}\left(\mathrm{CF}_{3}\right)_{2}\right) \mathrm{BAr}_{3}^{\mathrm{CF}}{ }_{3}\right\}\right]$ which, interestingly, undergoes a phase change at $323 \mathrm{~K}$ to give crystalline material, resulting in sharper signals. ${ }^{24}$ We have not investigated whether this occurs for $\left[\mathbf{1}-\mathrm{BAr}_{4}{ }_{4}\right](\mathrm{X}=\mathrm{F}, \mathrm{Cl}, \mathrm{H})$.

We have previously used ${ }^{1} \mathrm{H} /{ }^{13} \mathrm{C}$ FSLG-HETCOR SSNMR experiments ${ }^{57}$ to indirectly detect $\mathrm{Rh} \cdots \mathrm{H}-\mathrm{C}$ interactions in $\sigma$ alkane complexes. ${ }^{24,25,58}$ The HETCOR spectrum (158 K) of $[1-N B A]\left[\mathbf{B A r}_{4}{ }_{4}\right]$ (as prepared as a mixture with $\left[1-\mathbf{B A r}_{4}^{\mathrm{Cl}}\right]$ ) features a high-field ${ }^{1} \mathrm{H}$ cross-peak $(\delta-3.1)$ which correlates to a partially obscured ${ }^{13} \mathrm{C}$ signal at $\delta 25$ assigned to the NBA carbon atoms involved in the $3 c-2 e$ interaction (Supporting Information). We did not observe a distinctive cross peak for the bridge methylene group in NBA to high-field shifted proton signals. This is different from that in $[1-\mathrm{NBA}]\left[\mathrm{BAr}^{\mathrm{CF} 3}{ }_{4}\right]$, in which a ${ }^{13} \mathrm{C}$ signal at $\delta \sim 44$ correlates to a high-field shifted peak in the ${ }^{1} \mathrm{H}$ NMR projection that is due to these protons experiencing ring current shielding from the proximal 3,5$\left(\mathrm{CF}_{3}\right)_{2} \mathrm{C}_{6} \mathrm{H}_{3}$ groups in the lattice. ${ }^{24,58}$ This suggests a different structure for $[\mathbf{1 - N B A}]\left[\mathrm{BAr}_{4}^{\mathrm{Cl}}\right]$ (vide infra). We were not successful in obtaining a meaningful HETCOR spectrum of [1NBA $]\left[\mathrm{BAr}^{\mathrm{F}}{ }_{4}\right]$.

These data combined show that the $\left[\mathrm{BAr}^{\mathrm{CF} 3}{ }_{4}\right]^{-}$anion promotes fast hydrogenation of the NBD precursor to form a stable alkane complex as already reported. ${ }^{24}$ In comparison, although $[1-\mathrm{NBD}]\left[\mathrm{BAr}^{\mathrm{H}}{ }_{4}\right]$ shares a similar solid-state packing environment, hydrogenation is significantly slower, while anion coordination and alkane loss occurs at a comparable, likely faster rate, which means that the intermediate $\sigma$-alkane complex is not seen. For $[1-\mathrm{NBD}]\left[\mathrm{BAr}_{4}^{\mathrm{Cl}}\right]$ and $[1-\mathrm{NBD}]\left[\mathrm{BAr}_{4}^{\mathrm{F}}\right]$ the situation is more finely balanced. The motif present in [1$\mathrm{NBD}]\left[\mathrm{BAr}^{\mathrm{F}}{ }_{4}\right.$, with $\mathrm{C}-\mathrm{H} \cdots \mathrm{F}$ interactions, clearly inhibits the hydrogenation of the coordinated $\mathrm{NBD}$, while the relative lack of stability of the corresponding $\sigma$-alkane complex, [1$\mathrm{NBA}]\left[\mathrm{BAr}^{\mathrm{F}}{ }_{4}\right]$, with respect to zwitterion $\left[\mathbf{1 - B A r ^ { \mathrm { F } }}{ }_{4}\right]$ means that this complex is never observed as the major species. For $[1-\mathrm{NBA}]\left[\mathrm{BAr}_{4}^{\mathrm{Cl}}\right]$, this situation is balanced more in favor of the alkane complex over starting material. Although the rate of hydrogenation is essentially the same as that for [1-NBD]-
$\left[\mathrm{BAr}_{4}^{\mathrm{H}}\right]$, the alkane complex is persistent and can be observed alongside amorphous $\left[1-\mathrm{BAr}_{4}{ }_{4}^{\mathrm{Cl}}\right]$. These observations indicate that the fluorous $-\mathrm{CF}_{3}$ groups may facilitate $\mathrm{H}_{2}$ transport through the nonporous crystal ${ }^{35,59-62}$ and/or permit rearrangement of the NBD fragment necessary to promote hydrogenation and formation of a $\sigma$-alkane complex, while retaining the same microenvironment of $\left[\mathrm{BAr}_{4}^{\mathrm{CF} 3}\right]^{-}$anions to allow for subsequent observation of the $\sigma$-alkane complex.

2.3. Characterization of a $\sigma$-Alkane Complex by Single-Crystal X-ray Crystallography. The temporal profile of hydrogenation coupled with the relative lifetime of the $\sigma$ alkane complex encouraged a single-crystal to single-crystal study of the hydrogenation of [1-NBD] $\left[\mathrm{BAr}^{\mathrm{Cl}}{ }_{4}\right] . \mathrm{H}_{2}$ was added to crystalline material ( 2 bar, $298 \mathrm{~K}$ ) and a selected singlecrystal rapidly transferred to the cryostream $(150 \mathrm{~K})$ of an Xray diffractometer. This procedure was repeated a number of times to optimize the hydrogenation time $(30 \mathrm{~min})$ to obtain the highest-quality structure. Under these temporal conditions (cf. Figure 4), the best solution still had $\sim 7 \%$ [1-NBD]$\left[\mathrm{BAr}_{4}{ }_{4}\right]$ in the lattice that could be adequately accounted for at this partial occupancy. Longer reaction times $(>1 \mathrm{~h})$ afforded solids that had lost long-range order, i.e., Figure $5 \mathrm{~B}$. The solidstate structure of $[\mathbf{1 - N B A}]\left[\mathbf{B A r}^{\mathrm{Cl}}{ }_{4}\right]$ is shown in Figure $7 \mathrm{~A}$. This single-crystal to single-crystal transformation proceeds without a change in space group $(P \overline{1})$ or the overall structural motif of
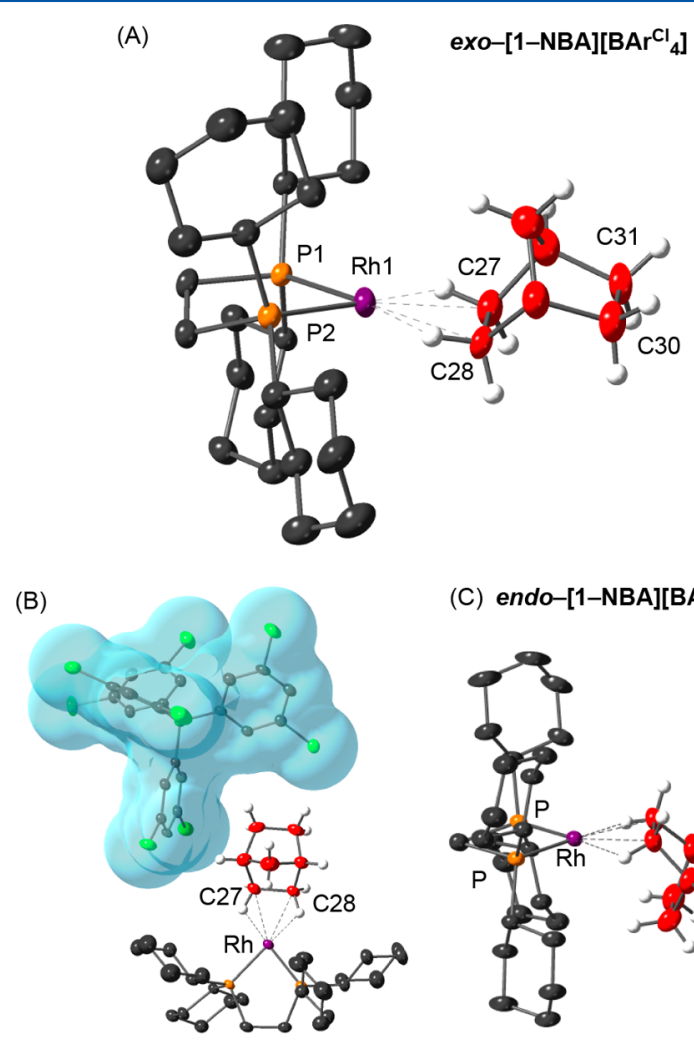

(C) endo-[1-NBA][BAr ${ }^{\mathrm{CF}_{3}}$ ]

Figure 7. (A) Solid-state structures of the cations in exo-[1NBA] $\left[\mathrm{BAr}_{4}^{\mathrm{Cl}}\right]$. Displacement ellipsoids are shown at $50 \%$ probability level. Hydrogen atoms excepting those on the alkane fragment omitted for clarity. Selected bond lengths ( $\AA)$ : Rh1-P1 2.2095(11), Rh1-P2 2.2059(12), Rh1-C27 2.387(5), Rh1-C28 2.378(5), C27-C28 1.561(7), C30-C31 1.548(9). (B) Relationship between the [1NBA $]^{+}$cation and the proximal $\left[\mathrm{BAr}_{4}^{\mathrm{Cl}}\right]^{-}$anion (van der Waals surface shown). (C) Molecular structure of the cation in [1$\mathrm{NBA}]\left[\mathrm{BAr}_{4}^{\mathrm{CF} 3}{ }_{4}\right]$ demonstrating the endo-coordination motif of the cation. $^{24}$ 
the anion-packing. The structural model is consistent with the coordination of norbornane with the metal center through two, $\eta^{2}, 3 \mathrm{c}-2 \mathrm{e} \mathrm{Rh} \cdots \mathrm{H}-\mathrm{C}$ bonds. The $\mathrm{Rh}-\mathrm{C} 27 / \mathrm{C} 28$ distances [2.387(5) and 2.378(5) $\AA$, respectively] are the same within error as those reported for $[\mathbf{1}-\mathbf{N B A}]\left[\mathbf{B A r}_{4}^{\mathrm{CF} 3}\right][2.389(3)$ and $2.400(3) \AA] .^{24}$ The $\mathrm{C} 27-\mathrm{C} 28$ and $\mathrm{C} 30-\mathrm{C} 31$ distances [1.561(7) and 1.548(9) $\AA$ ] confirm the hydrogenation of the diene to afford an alkane. The $\mathrm{Rh}-\mathrm{P}$ distances are shorter than in the precursor NBD complex, e.g., Rh-P1, 2.2095(11), cf. 2.3008(6) $\AA$, and reflect the low trans influence of the $\sigma$ alkane interaction.

The hydrogen atoms associated with $\mathrm{C} 27$ and $\mathrm{C} 28$, i.e., the $3 c-2 e$ interactions, were located and their positions refined in the final model. These, and the relative orientation of the NBA fragment, show it is the exo-hydrogens of the NBA methylene groups $\mathrm{C} 27 / \mathrm{C} 28$ that are interacting with $\mathrm{Rh}$-center. This is in contrast to the identical cation in [1-NBA] $\left[\mathrm{BAr}^{\mathrm{CF} 3}{ }_{4}\right]$ (Figure 7C) in which it is the endo- $\mathrm{CH}$ groups that interact with the metal center. ${ }^{24}$ This different orientation is thus due to the different anion packing in the solid-state. Closer inspection of the relationship between cation and proximal anion in [1NBA] $\left[\mathrm{BAr}_{4}{ }_{4}\right]$ (Figure $7 \mathrm{~B}$ ) reveals that the NBA bridge methylene group (C33) does not sit in the cleft of two aryl groups, as found in [1-NBA] $\left[\mathbf{B A r}^{\mathrm{CF} 3}{ }_{4}\right]$ (Figure 1B), but instead the anion sits off to one side. This is consistent with the ${ }^{1} \mathrm{H} /{ }^{13} \mathrm{C}$ HETCOR studies that indicates that there are no ring-current shielded methylene groups in the solid-state.

Previous calculations on the isolated cation $[1-N B A]^{+}$have shown that the exo-and endo-forms are essentially isoenergetic and can be interconverted by a low-energy rocking motion $\left(\right.$ TS $_{\text {rock }}, 9.1 \mathrm{kcal} / \mathrm{mol}$, Figure $\left.8 \mathrm{~A}\right)$. However, when placed in the

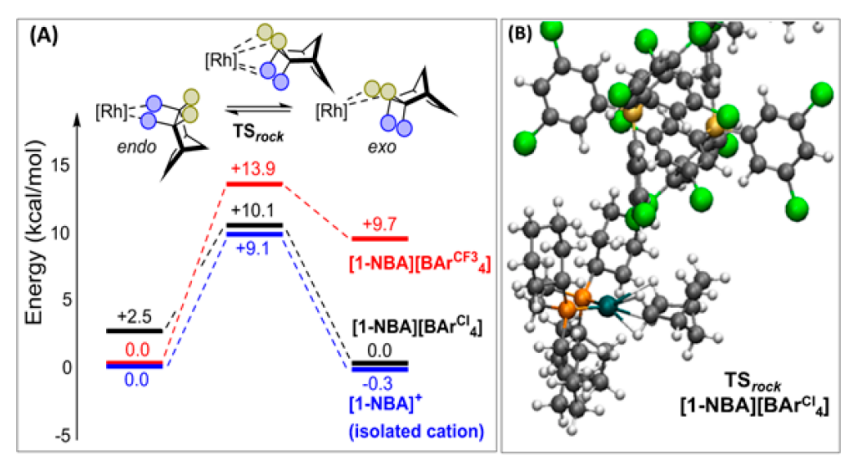

Figure 8. (A) Relative energies of endo- and exo-NBA isomers in [1$\mathrm{NBA}]^{+}$as a function of anion and their barriers for interconversion via $\mathrm{TS}_{\text {rock }}$ (B) Detail of the structure of $\mathbf{T S}_{\text {rock }}$ computed in the solid-state for $[1-N B A]\left[B^{2} r^{\mathrm{Cl}}{ }_{4}\right]$. Method: [CP2K]PBE-D3/DZVP-MOLOPTSR-GTH/GTH-PBE (cutoff $500 \mathrm{Ry}$ ).

extended crystal environment periodic DFT calculations on [1NBA] $\left[\right.$ BAr $\left.^{\mathrm{CF} 3}{ }_{4}\right]$ revealed that the endo-isomer is now clearly favored by $9.7 \mathrm{kcal} / \mathrm{mol}$, while the exo-isomer was kinetically accessible with a barrier to interconversion of $13.9 \mathrm{kcal} / \mathrm{mol}$, albeit at very low equilibrium populations. ${ }^{30}$ For [1-NBA]$\left[\mathrm{BAr}_{4}^{\mathrm{Cl}}\right]$, this situation is reversed. The most stable isomer is now exo-[1-NBA] $\left[\mathrm{BAr}^{\mathrm{Cl}}{ }_{4}\right]$, with the endo-isomer at $2.5 \mathrm{kcal} /$ mol being kinetically accessible via $\mathbf{T S}_{\text {rock }}$ and a slightly smaller barrier of $10.1 \mathrm{kcal} / \mathrm{mol}$ (see Figure $8 \mathrm{~B}$ and Supporting Information). These calculations are fully consistent with the observed, crystallographically determined structures and highlight the importance of considering the extended environment rather than isolated metal-ligand complexes when discussing these solid-state structures. Interestingly, the exo-coordination of $\mathrm{C}-\mathrm{H} \cdots \mathrm{Rh}$ interactions observed in $[\mathbf{1 - N B A}]\left[\mathrm{BAr}_{4}^{\mathrm{Cl}}\right]$ reflect the intermediate implicated in selective solid/gas $\mathrm{H} / \mathrm{D}$ exchange processes in $[\mathbf{1}-\mathrm{NBA}]\left[\mathrm{BAr}^{\mathrm{CF} 3}{ }_{4} .^{30}\right.$

2.4. Selectivity of the NBD Hydrogenation and Subsequent $\mathrm{C}-\mathrm{H}$ Activation in the Solid-State. Reaction of $[1-\mathrm{NBD}]\left[\mathrm{BAr}^{\mathrm{CF} 3}{ }_{4}\right]$ with $\mathrm{D}_{2}$ in a solid/gas reaction $(5 \mathrm{~min})$ proceeds with $\sim 95 \%$ endo selectivity, forming endo,endo- $\mathrm{D}_{4^{-}}$[1NBA $]\left[\right.$ BAr $\left.^{\mathrm{CF} 3}{ }_{4}\right]$ as determined by GC-MS and ${ }^{1} \mathrm{H} /{ }^{2} \mathrm{H}$ NMR spectroscopy of the liberated NBA and single-crystal neutron diffraction. ${ }^{30}$ When $[\mathbf{1 - N B A}]\left[\mathrm{BAr}^{\mathrm{CF} 3}{ }_{4}\right]$ is exposed to $\mathrm{D}_{2}(16 \mathrm{~h})$ $\mathrm{C}-\mathrm{H}$ activation occurs at the remote, exo- $\mathrm{C}-\mathrm{H}$ bond, to give exo-D ${ }_{4}$ - $[1-\mathrm{NBA}]\left[\mathrm{BAr}^{\mathrm{CF} 3}{ }_{4}\right]$. No $\mathrm{H} / \mathrm{D}$ exchange was observed at the endo-sites despite it being these that interact with the $\mathrm{Rh}$ center. This latter experiment shows that the exo sites are both accessible (Figure 8) and kinetically competent for $\mathrm{C}-\mathrm{H}$ activation. That the $\mathrm{D}_{4}$ isotopologue is selectively formed also demonstrates a fluxional process is occurring in the solid-state that brings both sets of exo-C-H bonds to the Rh-center. This was shown experimentally and computationally to involve an initial low energy $C_{2}$ rotation of the NBA fragment in endo-[1$\mathbf{N B A}]\left[\mathbf{B A r}^{\mathrm{CF} 3}{ }_{4}\right]$. Interestingly, when $\left[\mathrm{Rh}\left({ }^{\mathrm{i}} \mathrm{Bu}_{2} \mathrm{PCH}_{2} \mathrm{CH}_{2}-\right.\right.$ $\left.\mathrm{P}^{\mathrm{i}} \mathrm{Bu}_{2}\right)\left(\eta^{2} \eta^{2}\right.$-NBD $\left.)\right]\left[\mathrm{BAr}{ }_{4}^{\mathrm{CF} 3}\right]$ is exposed briefly to $\mathrm{D}_{2}$ it results in endo- $\mathrm{D}_{2}$-exo- $\mathrm{D}_{2}-\mathrm{NBA}$, the different selectivity demonstrating reorganization in the solid-state via an intermediate NBE complex. $^{26}$

The selectivity of $\mathrm{H}_{2}$ addition to [1-NBD] $\left[\mathrm{BAr}_{4}^{\mathrm{X}}\right.$ ] $(\mathrm{X}=\mathrm{Cl}$, $\mathrm{F}, \mathrm{H})$ was similarly studied. Longer reaction times $(40 \mathrm{~h})$ and powdering of precursor employed due to the significantly slower rates of hydrogenation exhibited by these complexes relative to $[1-\mathrm{NBD}]\left[\mathrm{BAr}^{\mathrm{CF}}{ }_{4}\right]$. For $[1-\mathrm{NBA}]\left[\mathrm{BAr}_{4}^{\mathrm{Cl}}\right]$, the ${ }^{2} \mathrm{H}$ NMR spectrum of the liberated alkane (vacuum transferred using $\mathrm{CD}_{2} \mathrm{Cl}_{2}$ ) shows deuterium incorporation in both the endo- $\left(\delta\right.$ 1.16) and exo-sites $\left(\delta\right.$ 1.46) [Lit. $d_{4}$-methanol: 1.21 and 1.52 , respectively]. ${ }^{63}$ Relative integrals, calibrated to the bridgehead methine resonance, from the corresponding ${ }^{1} \mathrm{H}$ NMR spectrum show deuterium incorporation at the endo positions to be $\sim 90$ with $\sim 25 \%$ at the exo positions (Scheme 3 ). GC-MS indicated the major ion at $\mathrm{m} / z=100.1185$ which corresponds to $\mathbf{D}_{4}-\mathbf{N B A}$ (calcd $\mathrm{C}_{7} \mathrm{H}_{8} \mathrm{D}_{4}=100.1190$ ). Additional ions were observed at $m / z=102.1310\left(\right.$ calcd $\mathrm{C}_{7} \mathrm{H}_{6} \mathrm{D}_{6}=$

Scheme 3. $\mathrm{D}_{2}$ Addition to $[1-\mathrm{NBD}]\left[\mathrm{BAr}_{4}^{\mathrm{X}}\right]^{a}$

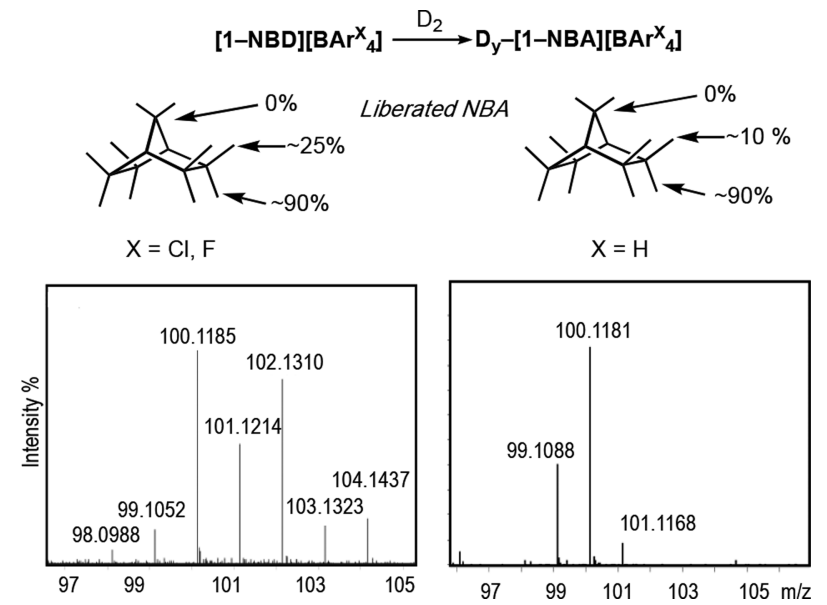

${ }^{a_{T}}$ The signal at $m / z=1$ is lower than the parent ion, i.e., $\mathrm{m} / \mathrm{z}=99.1$, which reflects the fragmentation pattern of NBA: NBA- $[\mathrm{H}]^{\bullet}$. 
$102.1315)$ and $m / z=104.1437\left(\right.$ calcd $\left.\mathrm{C}_{7} \mathrm{H}_{4} \mathrm{D}_{8}=104.1441\right)$ all with fragmentation patterns very similar to those of NBA, consistent with the incorporation of six and eight deuterium atoms, respectively. These data are consistent with reductive deuteration of the alkenes to form $\mathbf{D}_{4^{-}}[\mathbf{1}-\mathbf{N B A}]\left[\mathbf{B A r}^{\mathrm{Cl}}{ }_{4}\right]$ and subsequent $\mathrm{C}-\mathrm{H}$ activation of the alkane in a solid/gas reaction. Similar NMR and mass spectral data were obtained for the liberated alkane obtained via reaction of powdered [1$\mathrm{NBD}]\left[\mathrm{BAr}_{4}^{\mathrm{F}}\right.$ ] with $\mathrm{D}_{2}$. In contrast, GC-MS of NBA liberated from the analogous reaction with $[1-\mathrm{NBD}]\left[\mathrm{BAr}^{\mathrm{H}}{ }_{4}\right]$, features a single ion at $m / z=100.1181\left(\right.$ calcd $\mathrm{C}_{7} \mathrm{H}_{8} \mathrm{D}_{4}=100.1190$ ) consistent with deuteration of the double bonds only and that no $\mathrm{H} / \mathrm{D}$ exchange is occurring. This is consistent with the poor stability of $[1-\mathrm{NBA}]\left[\mathrm{BAr}^{\mathrm{H}}{ }_{4}\right]$ relative to those of $[1-\mathrm{NBA}]$ $\left[\mathrm{BAr}_{4}^{\mathrm{Cl}}\right]$ and $[\mathbf{1 - N B A}]\left[\mathrm{BAr}^{\mathrm{F}}{ }_{4}\right]$. The relative integrals in the ${ }^{1} \mathrm{H}$ NMR spectrum of the liberated NBA shows the deuterium addition is selective ( $90 \%)$ for the endo-faces.

The slow hydrogenation and poor stability of all the new $\sigma$ alkane complexes reported here meant that delineation of the selectivities of the initial hydrogenation and the H/D exchange reactions was not possible, unlike that for [1-NBA] $\left[\mathrm{BAr}^{\mathrm{CF} 3}{ }_{4}\right]$. Nevertheless, the observation of $90 \%$ endo $/ 25 \%$ exo deuterium incorporation for $[1-\mathrm{NBD}]\left[\mathrm{BAr}^{\mathrm{F}}{ }_{4}\right]$ and $[1-\mathrm{NBD}]\left[\mathrm{BAr}_{4}^{\mathrm{Cl}}\right]$ suggests that $H / D$ exchange occurs at the alkane as well as $\mathrm{D}_{2}$ addition to the alkene (which would only produce $100 \%$ total endo/exo D incorporation). Further evidence for $\mathrm{C}-\mathrm{H}$ activation at the bound alkane ligand in the solid-state comes from addition of $\mathrm{D}_{2}$ to $[1-\mathrm{NBD}]\left[\mathrm{BAr}_{4}^{\mathrm{Cl}}\right]$ or $[1-\mathrm{NBD}]\left[\mathrm{BAr}_{4}^{\mathrm{F}}\right]$ in $\mathrm{CD}_{2} \mathrm{Cl}_{2}$ solution, where the NBA ligand is lost to solvent coordination, ${ }^{24,26}$ and only deuteration of the double bonds is observed.

2.5. Catalytic 1-Butene Isomerization. We have previously shown ${ }^{31}[\mathbf{1 - N B A}]\left[\mathbf{B A r}_{4}^{\mathrm{CF} 3}\right]$ to be effective in solid-state molecular organometallic catalysis (SMOM-cat) for the isomerization of 1-butene to a mixture of cis-and trans-2butene at $298 \mathrm{~K}$ and $1 \mathrm{~atm}$. Studies suggest catalysis is likely dominated by active species near to the surface of the crystal, although the NBA ligand is readily displaced by alkene in the whole crystal. In situ prepared [1-NBA] $\left[\mathbf{B A r}^{\mathrm{X}}{ }_{4}\right](\mathrm{X}=\mathrm{Cl}, \mathrm{F}, \mathrm{H})$ enabled the effect of the anion on the catalytic isomerization of 1-butene to be studied. Catalysts were prepared by hydrogenation of $\sim 2 \mathrm{mg}$ of finely powdered NBD precursors in an NMR tube for $1 \mathrm{~h}$ to form the corresponding NBA-alkane complexes in the proportions shown in Figure 4B. These in situ prepared catalysts were then exposed to 1-butene gas, and the progress of the resulting solid/gas isomerization catalysis followed by gas-phase NMR spectroscopy and gas chromatography (Figure 9A). As shown previously, $[1-\mathrm{NBA}]\left[\mathbf{B A r}^{\mathrm{CF} 3}{ }_{4}\right]$ is a very effective catalyst, and the first measured point $(1 \mathrm{~min})$ shows that the thermodynamic equilibrium ${ }^{64}$ between 1-butene and 2-butene is almost reached at $94 \%$ conversion ( $\mathrm{ToN}=54$, $\left.\mathrm{ToF}_{(\min )}=3170 \mathrm{~h}^{-1}\right)$. Complexes $[\mathbf{1 - N B A}]\left[\mathbf{B A r}^{\mathrm{Cl}}{ }_{4}\right]$ and $[\mathbf{1 -}$ $\mathbf{N B A}]\left[\mathrm{BAr}^{\mathrm{F}}{ }_{4}\right]$ were both found to be active catalysts but were slower than [1-NBA] $\left[\mathrm{BAr}^{\mathrm{CF} 3}{ }_{4}\right]$. These systems are also active on recharging with 1-butene (Supporting Information). These recharging experiments showed slightly reduced $\mathrm{ToF}$ which we have previously commented upon as being due to the formation of [1-butadiene $]^{+}$, by a transfer dehydrogenation of 1-butene, which is a poorer catalyst. ${ }^{31}$

The relative rates of isomerization track the relative proportions of alkane complex formed after $1 \mathrm{~h}$ of hydrogenation (Figure 4B). Figure 9B compares relative conversion after 2 and $60 \mathrm{~min}$, and $[\mathbf{1 - N B A}]\left[\mathbf{B A r}_{4}^{\mathrm{Cl}}\right]$ is faster than $[\mathbf{1 -}$
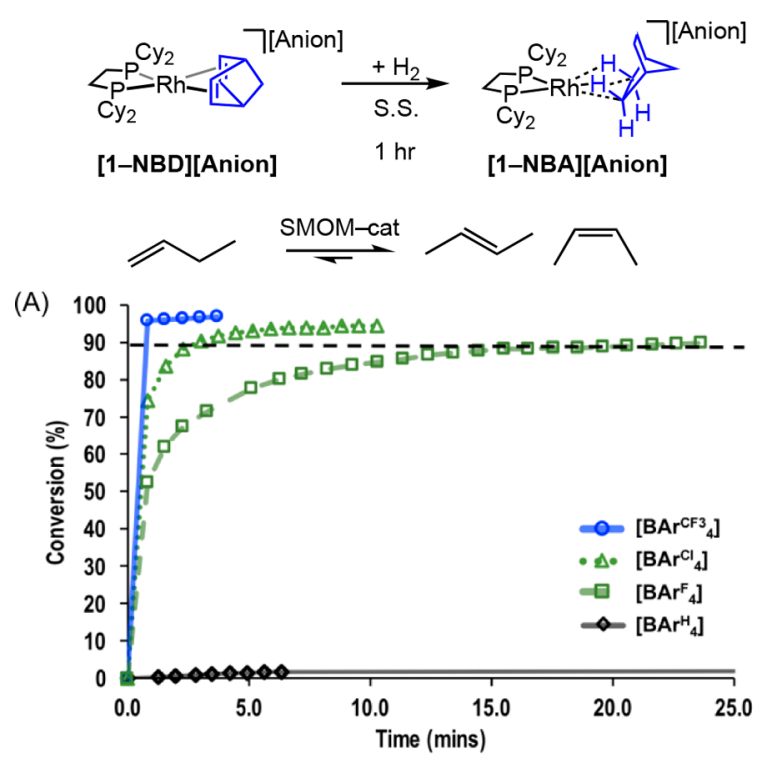

(B)

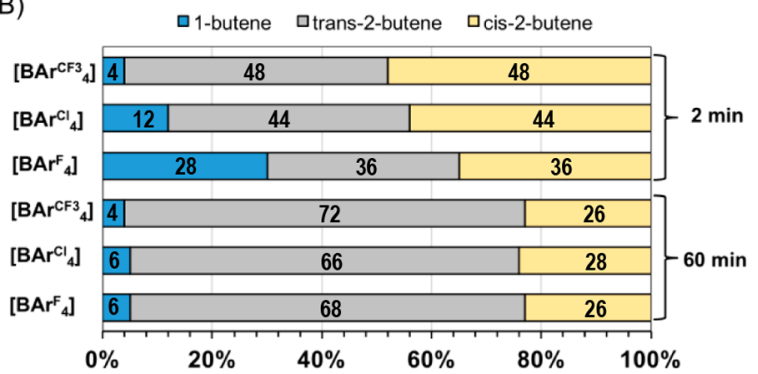

Figure 9. (A) Comparison of catalysts in the isomerization of 1-butene to 2-butene as measured by gas phase ${ }^{1} \mathrm{H}$ NMR spectroscopy. All catalysts $=\sim 2.0 \mathrm{mg}$ finely powdered sample. Complexes [1NBA] $\left[\mathbf{B A r}_{4}{ }_{4}\right](\mathrm{X}=\mathrm{Cl}, \mathrm{F}, \mathrm{H})$ were prepared in situ. 1-Butene $=1$ atm $(86 \mu \mathrm{mol}$ at $298 \mathrm{~K})$. Dashed line indicates $90 \%$ conversion. (B) Relative ratio of 1-butene, trans-2-butene, and cis-2-butene as measured by GC.

NBA] $\left[\mathrm{BAr}_{4}^{\mathrm{F}}\right.$ ], consistent with the higher proportion of NBA alkane complex present. All eventually reach close to the thermodynamic equilibrium for the 1-butene/2-butene ensemble. ${ }^{64}$ Precatalyst $[\mathbf{1 - N B D}]\left[\mathrm{BAr}^{\mathrm{H}}{ }_{4}\right]$ is essentially inactive post activation with $\mathrm{H}_{2}$, as the alkane complex is not persistent. Without $\mathrm{H}_{2}$ activation, all the NBD precatalysts are inactive for isomerization. These observations regarding catalyst activity and active-site structure are similar to those made by Bianchini and co-workers on the role of active-site isolation in solid/gas ethene hydrogenation using $\left[\operatorname{Ir}(\right.$ triphos $\left.)(\mathrm{H})_{2}\left(\mathrm{C}_{2} \mathrm{H}_{4}\right)\right][\mathrm{X}]$. ${ }^{37}$ When $\mathrm{X}=\left[\mathrm{BAr}_{4}^{\mathrm{H}}\right]^{-}$dimerization occurs at temperatures above $70{ }^{\circ} \mathrm{C}$ to form a much less active hydride bridged species. In contrast, when the much larger polyoxometalate $\left[\mathrm{PW}_{12} \mathrm{O}_{40}\right]^{3-}$ is used dimerization is avoided as the active sites are isolated.

Monitoring the 2-butene cis/trans ratio over time shows at the early stages of catalysis $(2 \mathrm{~min})$ a cis/trans ratio of $\sim 1: 1$ for all three active catalysts (Figure 9B). When left for an extended time $(60 \mathrm{~min})$ the ratio changes to be very close to the thermodynamic position of $\sim 1: 3$ at $298 \mathrm{~K}$. This demonstrates that cis-2-butene is the kinetic product, and we suggest this is driven by the relative stabilities of cis and trans isomers when bound to the $\mathrm{Rh}$ catalyst. ${ }^{31}$ The observed resting state in the $[1-\mathrm{NBA}]\left[\mathrm{BAr}_{4}^{\mathrm{CF} 3}{ }_{4}\right]$ system is the cis-isomer of [1-(2-butene)]$\left[\mathrm{BAr}^{\mathrm{CF} 3}{ }_{4}\right]$, an observation supported by periodic DFT 
calculations that show the cis-coordinated isomer to be 11.4 $\mathrm{kcal} / \mathrm{mol}$ more stable than the trans, reflecting the microenvironment imposed by the crystalline lattice, and $5.7 \mathrm{kcal} /$ mol more stable than the 1-butene complex. The initial 1:1 ratio observed here and then equilibration to the thermodynamic limit suggest reversible binding of the isomers of 2 butene post double-bond isomerization. Compared with the cis2-butene resting state, isomerization, and then loss of trans-2butene at the metal center presents the overall highest energy span within the system. Similar selectivity for cis- over trans-2butene has been noted for Pt-nanoparticle catalysts ${ }^{65}$ and is suggested to be due to the increased stability of the surfacebound cis-isomer. Homogeneous ${ }^{66}$ and surface supported organometallic systems (under propene metathesis conditions) have also been shown to show selectively at early stage of catalysis for cis-butene. ${ }^{67,68}$

\section{CONCLUSIONS}

The interplay between reactive cationic metal center and weakly coordinating anion is a well-established way of tuning structure, reactivity, and stability in homogeneous organometallic catalytic systems. We have extended this concept to solid-state molecular organometallic systems (SMOM) by using solid/gas reactivity to synthesize sometimes transient $\sigma$-alkane complexes and then benchmarked their reactivity for alkene isomerization. Although of the anions studied only $\left[\mathrm{BAr}{ }_{4}^{\mathrm{CF} 3}\right]^{-}$ affords indefinitely stable $\sigma$-alkane complexes, there is a strong correlation between the lifetime of the complexes and catalytic activity in 1-butene double bond isomerization. The relative rates of hydrogenation of the NBD precursors are less straightforward to rationalize, but it is clear that the $-\mathrm{CF}_{3}$ groups on the $\left[\mathrm{BAr}_{4}^{\mathrm{CF} 3}\right]$ anion play a significant role in both facilitating the movement of $\mathrm{H}_{2}$ through the essentially nonporous crystalline framework and stabilizing the lattice toward collapse. More generally, the ability for the anion framework to control the spatial orientation and stereochemistry of the bonding mode of the alkane ligand with the metal center, e.g., exo-[1-NBA] $\left[\mathrm{BAr}_{4}^{\mathrm{Cl}}\right]$, suggests future opportunities to harness the local microenvironment in SMOM systems to control selectivity in catalytic processes. ${ }^{60}$ This is similar to that recently reported in catalysts encapsulated in metal-organic frameworks that also offer a local spatial environment that promotes selectivity for one pathway over another. ${ }^{69}$

\section{ASSOCIATED CONTENT}

\section{S Supporting Information}

The Supporting Information is available free of charge on the ACS Publications website at DOI: 10.1021/acs.organomet.8b00215.

Experimental and characterization details, including NMR spectroscopic data, X-ray crystallographic data, and computational details (PDF)

Cartesian coordinates for calculated structures (XYZ)

Movies showing packing for $[\mathbf{1 - N B D}]\left[\mathrm{BAr}_{4}^{\mathrm{Cl}}\right],[\mathbf{1 -}$ $\mathrm{NBD}]\left[\mathrm{BAr}_{4}^{\mathrm{CF}}\right],[1-\mathrm{NBD}]\left[\mathrm{BAr}^{\mathrm{F}}{ }_{4}\right]$, and [1-NBD]$\left[\mathbf{B A r}^{\mathbf{H}}{ }_{4}\right]$ (MPG, MPG, MPG, MPG)

\section{Accession Codes}

CCDC 1836299-1836308 contain the supplementary crystallographic data for this paper. These data can be obtained free of charge via www.ccdc.cam.ac.uk/data_request/cif, or by emailing data_request@ccdc.cam.ac.uk, or by contacting The
Cambridge Crystallographic Data Centre, 12 Union Road, Cambridge CB2 1EZ, UK; fax: +44 1223336033.

\section{AUTHOR INFORMATION}

\section{Corresponding Authors}

*E-mail: andrew.weller@chem.ox.ac.uk (A.S.W.).

*E-mail: s.a.macgregor@hw.ac.uk (S.A.M.).

ORCID

Alasdair I. McKay: 0000-0002-6859-172X

Antonio J. Martínez-Martínez: 0000-0002-0684-1244

Andrew S. Weller: 0000-0003-1646-8081

Tobias Krämer: 0000-0001-5842-9553

Stuart A. Macgregor: 0000-0003-3454-6776

\section{Present Address}

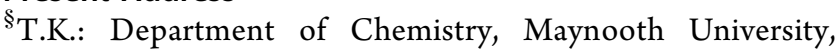
Maynooth, County Kildare, Ireland.

\section{Notes}

The authors declare no competing financial interest.

\section{ACKNOWLEDGMENTS}

We thank SCG Chemicals Co., Ltd, Thailand (A.S.W.) and the EPSRC (A.S.W., S.A.M.; EP/M024210, EP/K035908, EP/ K035681) for funding. This work used the ARCHER UK National Supercomputing Service (http://www.archer.ac.uk).

\section{REFERENCES}

(1) Goldberg, K. I., Goldman, A. S., Eds. Activation and Functionalization of $\mathrm{C}-\mathrm{H}$ Bonds; American Chemical Society, 2004.

(2) Choi, J.; MacArthur, A. H. R.; Brookhart, M.; Goldman, A. S. Chem. Rev. 2011, 111, 1761-1779.

(3) Goldberg, K. I.; Goldman, A. S. Acc. Chem. Res. 2017, 50, 620626

(4) Crabtree, R. H.; Lei, A. Chem. Rev. 2017, 117, 8481-8482. and references therein.

(5) Kubas, G. J. Metal Dihydrogen and $\sigma$-Bond Complexes; Kluwer Academic: New York, 2001.

(6) Arndtsen, B. A.; Bergman, R. G.; Mobley, T. A.; Peterson, T. H. Acc. Chem. Res. 1995, 28, 154-162.

(7) Crabtree, R. H. J. Chem. Soc., Dalton Trans. 2001, 2437-2450.

(8) Labinger, J. A.; Bercaw, J. E. Nature 2002, 417, 507-514.

(9) Cobar, E. A.; Khaliullin, R. Z.; Bergman, R. G.; Head-Gordon, M. Proc. Natl. Acad. Sci. U. S. A. 2007, 104, 6963-6968.

(10) Balcells, D.; Clot, E.; Eisenstein, O. Chem. Rev. 2010, 110, 749823.

(11) Weller, A. S.; Chadwick, F. M.; McKay, A. I. Adv. Organomet. Chem. 2016, 66, 223-276.

(12) Ball, G. E.; Brookes, C. M.; Cowan, A. J.; Darwish, T. A.; George, M. W.; Kawanami, H. K.; Portius, P.; Rourke, J. P. Proc. Natl. Acad. Sci. U. S. A. 2007, 104, 6927-6932.

(13) Hall, C.; Perutz, R. N. Chem. Rev. 1996, 96, 3125-3146.

(14) Cowan, A. J.; Portius, P.; Kawanami, H. K.; Jina, O. S.; Grills, D. C.; Sun, X.-Z.; McMaster, J.; George, M. W. Proc. Natl. Acad. Sci. U. S. A. 2007, 104, 6933-6938.

(15) Geftakis, S.; Ball, G. E. J. Am. Chem. Soc. 1998, 120, 9953-9954.

(16) Lawes, D. J.; Geftakis, S.; Ball, G. E. J. Am. Chem. Soc. 2005, 127, 4134-4135.

(17) Lawes, D. J.; Darwish, T. A.; Clark, T.; Harper, J. B.; Ball, G. E. Angew. Chem., Int. Ed. 2006, 45, 4486-4490.

(18) Calladine, J. A.; Torres, O.; Anstey, M.; Ball, G. E.; Bergman, R. G.; Curley, J.; Duckett, S. B.; George, M. W.; Gilson, A. I.; Lawes, D. J.; et al. Chem. Sci. 2010, 1, 622-630.

(19) Bernskoetter, W. H.; Schauer, C. K.; Goldberg, K. I.; Brookhart, M. Science 2009, 326, 553-556.

(20) Walter, M. D.; White, P. S.; Schauer, C. K.; Brookhart, M. J. Am. Chem. Soc. 2013, 135, 15933-15947. 
(21) Yau, H. M.; McKay, A. I.; Hesse, H.; Xu, R.; He, M.; Holt, C. E.; Ball, G. E. J. Am. Chem. Soc. 2016, 138, 281-288.

(22) Pike, S. D.; Weller, A. S. Philos. Trans. R. Soc., A 2015, 373, 20140187.

(23) Vittal, J. J.; Quah, H. S. Coord. Chem. Rev. 2017, 342, 1-18.

(24) Pike, S. D.; Chadwick, F. M.; Rees, N. H.; Scott, M. P.; Weller, A. S.; Krämer, T.; Macgregor, S. A. J. Am. Chem. Soc. 2015, 137, 820833.

(25) McKay, A. I.; Krämer, T.; Rees, N. H.; Thompson, A. L.; Christensen, K. E.; Macgregor, S. A.; Weller, A. S. Organometallics 2017, 36, 22-25.

(26) Pike, S. D.; Thompson, A. L.; Algarra, A. G.; Apperley, D. C.; Macgregor, S. A.; Weller, A. S. Science 2012, 337, 1648-1651.

(27) Inokuma, Y.; Kawano, M.; Fujita, M. Nat. Chem. 2011, 3, 349358.

(28) Copéret, C.; Comas-Vives, A.; Conley, M. P.; Estes, D. P.; Fedorov, A.; Mougel, V.; Nagae, H.; Núñez-Zarur, F.; Zhizhko, P. A. Chem. Rev. 2016, 116, 323-421.

(29) Thomas, J. M.; Thomas, W. J. Principles and Practice of Heterogeneous Catalysis, 2nd ed.; Wiley-VCH: Weinheim, 2015.

(30) Chadwick, F. M.; Krämer, T.; Gutmann, T.; Rees, N. H.; Thompson, A. L.; Edwards, A. J.; Buntkowsky, G.; Macgregor, S. A.; Weller, A. S. J. Am. Chem. Soc. 2016, 138, 13369-13378.

(31) Chadwick, F. M.; McKay, A. I.; Martinez-Martinez, A. J.; Rees, N. H.; Kramer, T.; Macgregor, S. A.; Weller, A. S. Chem. Sci. 2017, 8, 6014-6029.

(32) Macchioni, A. Chem. Rev. 2005, 105, 2039-2074.

(33) Riddlestone, I. M.; Kraft, A.; Schaefer, J.; Krossing, I. Taming the Cationic Beast: Novel Developments in the Synthesis and Application of Weakly Coordinating Anions. Angew. Chem., Int. Ed., 2018 DOI: 10.1002/anie.201710782.

(34) Siedle, A. R.; Newmark, R. A.; Brown-Wensley, K. A.; Skarjune, R. P.; Haddad, L. C.; Hodgson, K. O.; Roe, A. L. Organometallics 1988, 7, 2078-2079.

(35) Siedle, A. R; Newmark, R. A.; Sahyun, M. R. V.; Lyon, P. A.; Hunt, S. L.; Skarjune, R. P. J. Am. Chem. Soc. 1989, 111, 8346-8350.

(36) Bianchini, C.; Mealli, C.; Peruzzini, M.; Zanobini, F. J. Am. Chem. Soc. 1992, 114, 5905-5906.

(37) Bianchini, C.; Farnetti, E.; Graziani, M.; Kaspar, J.; Vizza, F. J. Am. Chem. Soc. 1993, 115, 1753-1759.

(38) Pike, S. D.; Weller, A. S. Dalton Trans. 2013, 42, 12832-12835.

(39) Spek, A. L. Acta Crystallogr., Sect. D: Biol. Crystallogr. 2009, 65, 148-155.

(40) Alvarez, S. Dalton Trans. 2013, 42, 8617-8636.

(41) Thalladi, V. R.; Weiss, H.-C.; Bläser, D.; Boese, R.; Nangia, A.; Desiraju, G. R. J. Am. Chem. Soc. 1998, 120, 8702-8710.

(42) Desiraju, G. R.; Parthasarathy, R. J. Am. Chem. Soc. 1989, 111, $8725-8726$.

(43) Boese, R.; Kirchner, M. T.; Dunitz, J. D.; Filippini, G.; Gavezzotti, A. Helv. Chim. Acta 2001, 84, 1561-1577.

(44) Dunitz, J. D.; Schweizer, W. B. Chem. - Eur. J. 2006, 12, 68046815

(45) Cavallo, G.; Metrangolo, P.; Milani, R.; Pilati, T.; Priimagi, A.; Resnati, G.; Terraneo, G. Chem. Rev. 2016, 116, 2478-2601.

(46) Desiraju, G. R. Science 1997, 278, 404-405.

(47) The bridgehead carbons are coincidental.

(48) At room temperature, dichloromethane solutions of [1-BAr $\left.{ }_{4}^{\mathrm{Cl}}\right]$ undergo $\mathrm{C}-\mathrm{Cl}$ activation of the anion to afford $\left[\mathrm{RhCl}\left(\mathrm{Cy}_{2} \mathrm{PCH}_{2}-\right.\right.$ $\left.\left.\mathrm{CH}_{2} \mathrm{PCy}_{2}\right)\left\{\mathrm{C}_{6} \mathrm{H}_{3} \mathrm{Cl}\left(\mathrm{BAr}_{3}\right)\right\}\right]_{2}$ which precipitates from solution. Hence, the data presented in Figures 4 and 5 represent the minimum amount of $[1-\mathrm{NBA}]\left[\mathrm{BAr}^{\mathrm{Cl}}{ }_{4}\right]$ formed. See Supporting Information.

(49) An increased pressure of hydrogen was employed to accelerate the hydrogenation of the alkene

(50) Albano, P.; Aresta, M.; Manassero, M. Inorg. Chem. 1980, 19, $1069-1072$.

(51) Longato, B.; Pilloni, G.; Graziani, R.; Casellato, U. J. Organomet. Chem. 1991, 407, 369-376.

(52) Shestakova, E. P.; Varshavsky, Y. S.; Khrustalev, V. N.; Podkorytov, I. S. J. Organomet. Chem. 2007, 692, 4297-4302.
(53) Grochowski, M. R.; Morris, J.; Brennessel, W. W.; Jones, W. D. Organometallics 2011, 30, 5604-5610.

(54) Schrock, R. R.; Osborn, J. A. Inorg. Chem. 1970, 9, 2339-2343.

(55) Li, X.; Baldamus, J.; Nishiura, M.; Tardif, O.; Hou, Z. Angew. Chem., Int. Ed. 2006, 45, 8184-8188.

(56) Bouwkamp, M. W.; Budzelaar, P. H. M.; Gercama, J.; Del Hierro Morales, I.; de Wolf, J.; Meetsma, A.; Troyanov, S. I.; Teuben, J. H.; Hessen, B. J. Am. Chem. Soc. 2005, 127, 14310-14319.

(57) Smart, K. A.; Grellier, M.; Coppel, Y.; Vendier, L.; Mason, S. A.; Capelli, S. C.; Albinati, A.; Montiel-Palma, V.; Muñoz-Hernández, M. A.; Sabo-Etienne, S. Inorg. Chem. 2014, 53, 1156-1165.

(58) Chadwick, F. M.; Rees, N. H.; Weller, A. S.; Krämer, T.; Iannuzzi, M.; Macgregor, S. A. Angew. Chem., Int. Ed. 2016, 55, 36773681.

(59) The solvent accessible voids in $[1-\mathrm{NBD}]\left[\mathrm{BAr}^{\mathrm{CF} 3}{ }_{4}\right]$ were found to account for $0.8 \%$ of the total unit cell volume.

(60) Huang, Z.; White, P. S.; Brookhart, M. Nature 2010, 465, 598601.

(61) Vitorica-Yrezabal, I. J.; Minguez Espallargas, G.; Soleimannejad, J.; Florence, A. J.; Fletcher, A. J.; Brammer, L. Chem. Sci. 2013, 4, 696708.

(62) Thallapally, P. K.; Peter McGrail, B.; Dalgarno, S. J.; Schaef, H. T.; Tian, J.; Atwood, J. L. Nat. Mater. 2008, 7, 146.

(63) Nguyen, B.; Brown, J. M. Adv. Synth. Catal. 2009, 351, 13331343.

(64) Kapteijn, F.; van der Steen, A. J.; Mol, J. C. J. Chem. Thermodyn. $1983,15,137-146$.

(65) Lee, I.; Delbecq, F.; Morales, R.; Albiter, M. A.; Zaera, F. Nat. Mater. 2009, 8, 132.

(66) Tolman, C. A. J. Am. Chem. Soc. 1972, 94, 2994-2999.

(67) Salameh, A.; Baudouin, A.; Soulivong, D.; Boehm, V.; Roeper, M.; Basset, J.-M.; Copéret, C. J. Catal. 2008, 253, 180-190.

(68) Chen, C.; Dugan, T. R.; Brennessel, W. W.; Weix, D. J.; Holland, P. L. J. Am. Chem. Soc. 2014, 136, 945-955.

(69) Grigoropoulos, A.; McKay, A. I.; Katsoulidis, A. P.; Davies, R. P.; Haynes, A.; Brammer, L.; Xiao, J.; Weller, A. S.; Rosseinsky, M. J. Angew. Chem., Int. Ed. 2018, 57, 4532-4539. 